\title{
Effectiveness of Guidance and Counseling Services on Adolescent Self- concept in Khwisero District, Kakamega County
}

\author{
Kenneth Otieno Olando \\ Dept. of Educational Psychology, Masinde Muliro University of Science and Technology, \\ Kakamega. \\ Email: jagem31@yahoo.com \\ Beatrice A. Otenyo (Corresponding author) \\ Dept. of Educational Psychology, Masinde Muliro University of Science and Technology, \\ Kakamega. \\ E-mail: otenyoabc@gmail.com \\ Peter Odera \\ Dept. of Educational Psychology, Masinde Muliro University of Science and Technology, \\ Kakamega. \\ Email: poajagempj@yahoo.com
}

Doi:10.5296/ijhrs.v4i4.6498 URL: http://dx.doi.org/10.5296/ijhrs.v4i4.6498

\begin{abstract}
Self concept is one's self identity. It's a representation of a person's own perceived beliefs, attitudes, competencies and characteristics. The researcher was motivated to make a study on the effectiveness of guidance and counseling services on adolescent self concept in schools within Khwisero district, in Kakamega County. The study adopted a descriptive survey research design. The district has a total of 24 public and 3 private secondary schools. The study used a target population sample of 240 students, 6 principals, 6 teacher counselors, and 3 education officials from 8 schools. Stratified random sampling and purposive and stratified techniques were used to sample the required schools according to their categories, select students, teachers and principals. The principals, teachers and student s' questionnaires were administered. An interview schedule for education officials was also given. To establish the reliability of the research instruments of the study, Pearson's Product Correlation Coefficient was computed; yielding a correlation coefficient of 0.87 .The study findings revealed that there was positive correlation between effective guidance and counseling services and promotion of positive adolescent self concept. This study significantly assists education stake holders to develop and improve the self esteem of their learners. It's hoped that the Ministry of Education should provide guidelines on the implementation of effective guidance and counseling strategies and their relevance.
\end{abstract}


Keywords: Guidance and Counseling, Self -Concept

\section{Introduction}

Guidance and counseling refers to a helping concept and relationship in which specific skills and techniques are used to make students competent, creative, realistic and able to make responsible decisions. Self concept refers to ones self identity, an organization of beliefs and attitudes about one self expressed in one's characteristics and competencies. According to Ndambuki (2011) who quoted Weiten, (1983) and Atelo, (2007) point out that self concept is the chacteristic behavior that brings out one's individuality which includes the physical, social, intellectual, moral and emotional self. These are boosted by the learners' immediate environment, family, and school in their vital interactions and subsequent development of self esteem which is an aspect of self concept.

The guidance and counseling department in schools, specifically provides expert direction which promotes the student self growth and wise decision making. This is done through teaching, advising, instructing, explaining, and opinion giving that enables learners develop self esteem (Nguyia, 2010). They also develop their personal needs and evaluate the societal challenges facing them, abilities and gradually develop life's goals that are individually satisfying and socially acceptable (UNESCO, 2000).

Adolescents in contemporary societies are exposed to environmental conflicts, and stressful situations unlike in the traditional past. The above influences lead to revolts, confusion, alienation and estrangement. The students exhibit nervousness, lack of confidence emotionally, mentally and morally Erickson Theory (Corey 2005). Through effective guidance and counseling services therefore, fundamental assistance would enable them develop positive self concept that further helps them experience psychological wellbeing and mental wholeness that results in academic excellence.

According to Maslow's Theory, (1954) if both intrinsic and extrinsic motivational needs are given, the adolescent learner will have a high sense of self esteem which makes them understood and appreciative of the world around them. They are also able to set realistic goals and face challenges in life. Evidently, positive self esteem in adolescent is a crucial aspect of healthy contended living and expresses an approval and disapproval attitude which indicates the extent to which the adolescent learner believes himself capable, successful and worthy. Based on adolescent needs the guidance and counseling department should promote and provide plans, appraisals, information and counseling services whose efficiency depends on balancing among corrective, preventive and developmental functions. The necessary cooperation from the teaching fraternity, parents, administrations, peer counselors and the guidance and counseling departments essentially creates a strong relationship to assist the adolescent learners gain positive self concept. The programmes put in place need consistence evaluation Osore (2009).

Maslow (1954) observed that organic behavior is dominated and organized by unsatisfied 
needs. The self esteem needs include the desire for strength, achievements, respect, dignity, independence confidence and status. An adolescent learner feels de-motivated and demoralized when their needs are inadequate. This lowers their self concept and academic input which leads to indiscipline. The guidance and guiding stakeholders should endeavor to provide both the physiological and psychological needs of adolescent learners to manage defiant behaviors like aggressiveness, hostility and frustrations. If the learning atmosphere is conducive the adolescent learner will be motivated to excel and feel good about themselves. Their self esteem enables them to succeed in what seems impossible. They are never be afraid of challenging situations and will never worry about failure when confident

Research by Stoufe and Coupper (1988) revealed that comparatively boys have a more powerful self concept than girls. They think confidently, realistically and effectively. Research in Kenya has also documented that self concept is related to academic achievement (Mwaniki, 2003 Ondeche, 2005 and Otelo, 2005). Self concepts determine learners' academic performance and raise their internal locus of control. It's' also an avenue of anchorage of life skills in ones' personality.

\section{Research Methodology}

A descriptive survey design was adopted for the study. The study was carried out in Khwisero district, Kakamega County. The district has an average size of 97 square kilometers. It's administratively divided into four divisions, six locations and 23 sub-locations. It has mainly a rural population with $70 \%$ living below poverty line.

The study used a target of 240 secondary students, six guidance and counseling coordinators, and six principals from six schools. Stratified and random sampling techniques were used to sample the required schools according to their status and also select the students. They were categorized into single pure boys' and girls' schools mixed boarding schools and mixed day schools. The principals were selected using saturated sampling while the teacher coordinators were selected using purposive sampling. Questionnaires for the principal, teacher coordinator and students were used and interview schedules were used for education officials to collect data. To establish the reliability of the research instruments, a pilot study was carried out in one of the schools which were not included in the final analysis of the data. The Pearson Product Correlation was used to analyze data and it yielded a correlation co-efficiency of 0.87 .

The results of the pilot study revealed that the research instruments were reliable and possessed both content and face validity. The quantitative data was analyzed by use of descriptive statistics. Qualitative data from principals, teacher coordinators and student questionnaires were analyzed using inferential statistics and the calculation of the Pearson Product Correlation. This helped to establish the relationship between independent variable (guidance and counseling services) and dependent variables (adolescent self concept). 
3. Result and Discussions

Table 1. Type of Schools

\begin{tabular}{|l|r|l|}
\hline \multicolumn{1}{|c|}{ Variables } & Frequency & Percentage \\
\hline Mixed Day & 2 & \\
& & 33.3 \\
\hline Mixed Day \&Boarding & 2 & \\
\hline Boys' Boarding & 1 & 33.3 \\
\hline Girls' Boarding & 1 & 16.7 \\
\hline Total & 6 & 16.7 \\
\hline
\end{tabular}

Table 1 above presents types of schools used for study in Khwisero District. The study findings reveal that many research respondents came from the coeducational institutions at $33.3 \%$, respectively, while $16.7 \%$ were from pure/single sex schools. Co educational institutions enable adolescent learners to interact positively and therefore develop healthy relations. Their sexual awareness creates confidence, self and social understanding that further creates optimism and good study habits.

Table 2. Age Brackets of students

\begin{tabular}{|c|r|c|}
\hline \multicolumn{1}{|c|}{ Age in years } & Frequency & Percentage \\
\hline $14-16$ & 64 & 22.0 \\
\hline $17-19$ & 137 & 61.0 \\
\hline $20-22$ & 39 & 17.0 \\
\hline Total & 240 & 100 \\
\hline
\end{tabular}

The table above presents the age bracket of students in the research area. The study finding in Table 2 reveal that the majority of the respondents 137 (61.0\%) were aged between 17-19 years. Further, 39 students $(17.0 \%)$ were aged between 20-22 years, while 84(32\%) were aged between 14-16 years. This implies that most students were in their adolescent stage when their identity, mental and behavioral activities are effected. They discover their personal needs, evaluate their abilities, and gradually develop life's' goals that are individually satisfying and socially acceptable. According to Corey, (2005) Ericksons Theory categorized this stage of personality development as identity crisis verses role diffusion.

Table 3. Strategies used in Guidance and Counseling Departments

\begin{tabular}{|l|l|l|l|l|}
\hline \multirow{2}{*}{ Counseling strategies } & Yes & & No & \\
\cline { 2 - 5 } & $\mathrm{F}$ & $\%$ & $\mathrm{~F}$ & $\%$ \\
\hline Peer Counseling & 220 & 92 & 20 & 08 \\
\hline Group counseling & 200 & 83 & 40 & 17 \\
\hline Individual counseling & 210 & 88 & 30 & 13 \\
\hline External Personnel & 232 & 97 & 08 & 03 \\
\hline
\end{tabular}

Table 3 illustrates the major techniques used to enhance counseling services in schools within 


\section{Macrothink

Khwisero District, Kakamega County. As Table 3 illustrates, students reported that teacher coordinators employed the following techniques to improve counseling services. Peer Counseling 220 (92\%), Group Counseling 200 (83\%), Individual Counseling 210 (88\%), and use of external resources $232(97 \%)$. These influenced the effectiveness of counseling issues on adolescent self concept in schools within Khwisero district. The frequency with which they are used is an added advantage to the learners' scholarly attitudes and behaviour development. 
Table 4. Results of Relationship between Effective Counseling Services and Adolescent Self Concept.

\begin{tabular}{|l|l|l|}
\hline Variables & No of students & Percentage \\
\hline 1 encouraged positive self concept & 238 & 99.3 \\
\hline 2 created positive relations at school and home & 234 & 97.5 \\
\hline 3 encouraged positive academic attitude & 230 & 95.8 \\
\hline 4 encouraged regular school attendance & 224 & 93.3 \\
\hline 5 promotion of good study habits & 235 & 97.9 \\
\hline 6 acceptable behavioral attitudes & 232 & 96.6 \\
\hline 7 acquire life skills & 229 & 94.4 \\
\hline 8 improved communication abilities & 226 & 953 \\
\hline 9 discussed adolescent sexuality issues & 211 & 87.9 \\
\hline 10 made informed choices on relationships & 211 & 87.9 \\
\hline 11 developed optimism and locus control & 209 & 87 \\
\hline 12 valued use of diverse counseling strategies & 232 & 96.6 \\
\hline 13 have low self esteem & 23 & 9.58 \\
\hline 14 are indiscipline & 47 & 19.5 \\
\hline 15 poor academic performance & 39 & 16.2 \\
\hline
\end{tabular}

Table 4 shows the results of the relationship between counseling services and adolescent self concept in Khwisero district. From Table 4, the study confirmed that an overwhelming majority of students valued effective counseling services as was evident in the results. Over 95\% of the respondents felt that counseling services encouraged positive self esteem, healthy relations both at school and home, promotion of good study habits, acceptable behavioral attitudes, and positive academic outlook.

More over, an overwhelming percentage (95\%), responded that they were able to communicate effectively, make informed choices on relationships, felt optimistic about the future, and valued diverse counseling techniques employed to affect high self esteem. The results also indicate that $88 \%$ of the students discussed adolescent sexuality issues and acquired life skills, which further enhanced their positive self concept. Alternatively, lack of positive self concept results in low academic output 16\%, indiscipline $20 \%$ and low self-esteem $10 \%$.

The above research findings established that effective guidance and counseling services positively affected the self concept of adolescent students hence their improved behavioral and academic status in Khwisero district. This is supported by Ndung'u (2006), Atelo (2007) and Nyamoma (2011) who observed in their studies, that a greater majority of secondary students have their self concepts developed and improved by various counseling strategies. Peer, individual, and group counseling strategies, and also invitation of external personnel to schools effectively help to acquire life skills, communicate effectively and make informed choices on relationships, academics and adolescent sexuality after discussions. These create active involvement and a positive self concept that results in resolving apparent challenges as observed by the psycho analytic theories of Freud, Carl Rodgers, and Adler (Corey, 
2005).They also encourage self commitment, accelerated maturity, and improved self concept.

Diverse counseling strategies aim at achieving self integration, self direction and responsibility which create therapeutic effectiveness and a reliable psychological climate for learning. This was an added advantage to the effectiveness of guidance and counseling on adolescent self concept in schools within Khwisero district. Lack of effective counseling mechanisms creates de-motivated and unrealistic students morally, socially and academically. They are prone to delinquent behaviour, exhibit low self esteem and achievement. Generally they have over all lower levels of psychological functioning as observed by Baumrinds Theory, (1982).

According to Ndambuki (2011), and Ondeche (2007), who quoted Maslow's Theory (1954), a student with high self esteem is focused, responsible and makes high academic achievements. These contrasts with students that have low self esteem who feel negative, emotionally intolerant, and socially, morally incompetent. Such students lack sense of security, life- skills and acceptance required to cope with apparent societal challenges.

The findings further confirmed that lack of parental considerations of the adolescents' academic potential negatively affect his/her self concept. Moreover, adolescent learners with low self esteem avoid creativity, are negative, feel unloved and withdrawn, blames others for his/her inadequacies, feel emotionally indifferent, is unable to tolerate normal frustration levels, are easily influenced by peer pressure and also overlooks their talents and abilities Child Development Institute (2008).

\section{Conclusion and recommendations}

It's imperative that adolescent self concept be developed and improved to produce responsible adults. Education stakeholders who include teachers, their school administration, parents and education officials should consider assisting their students develop a high sense of self esteem and improve their academic potential. The schools' guidance and counseling departments should establish effective mechanisms that will significantly improve on those learners who display a low self esteem and indiscipline behavior.

The study further established that there is a strong co-relation between guidance and counseling services and promotion of positive self concept in adolescent learners. It's signicant that education stakeholders invest in time, resources and love for their growing children that enhance knowledge, skills through effective counseling services. These promote positive self concept that further determines acceptable behaviour and academic achievements. Through peer, individual, group techniques and use of external resources, self concept in learners can positively be promoted.

Based on the conclusions of the findings made, the researcher arrived at the following 
recommendations: The Ministry of Education should provide and emphasize on guidelines and the implementation of diverse effective guidance and counseling strategies to develop and improve self concept. If students are exposed to the above, they'll transform their negative attitudes, have self direction and self growth that result in focused and responsible adults.

\section{Acknowledgement}

I am greatly indebted to my co-authors, respondents and Masinde Muliro University of Science and Technology for their support.

\section{References}

Atelo, C.H. (2007), Gender Disparities and Education in Rural Kisumu East. Unpublished M.Ed Thesis.Moi University.

Baker, S.D. \& Gerler, R. (2005). Counseling in Schools. Thousand Oaks, Sage Publications.

Baumrind, D. \& Black A.E. (1982). Socialization practices associated with dimensions of competence in pre-school boys and girls. Child Development, 38,294-349.

Child Development Institute. (2008).Child's Self -Esteem and Parenting Style. Journal of Cross Cultural Psychology.Michgan Child Welfare Needs Assessment. In Yeloune and J.F. White Edition. Choice and Control in America Education.

Corey,G (2005). Theory and Practice of Counseling and Psychotherapy ( $7^{\text {th }}$ Edition) Belmont:Brooke \& Cole.

Coppersmith, S. (2002). Self Esteem Inventories Manual. Mind Garden, Inc San.

Kerlinger, F.N. (1973).Foundations of Behavioral Research. New York. Holt, Rinchart Winstone Inc.

Kibui, F.N. (2005). Attitudes of Secondary School Students towards Seeking Counseling Help in Nyandarua District. Unpublished M.Ed Thesis, Kenyatta University.

Kothari, C R. (2004). Research Methodology. New Delhi, Daharmash Printers. India.

Maslow, A. (1954). Motivation \& Personality. Mc Graw Hill

Book Company, New York Harper.

Ndambuki, S.M. \& Thairu, B.A (2011). The Role of Counseling in Adolescent Development in Mukurweini District. Unpublished M.Ed Thesis. Kenyatta University.

Ndun'gu J.B. (2006). A study of Types of Guidance and Counseling Services 


\section{Macrothink

in Secondary Schools in Municipality Division of Nyeri Distrit.Unpublished M.Ed Project, Kenyatta University.

Nguyia, G. (2010).The Role of Guidance and Counseling in Schools in Makueni District. Unpublished M.Ed Thesis. University of Nairobi.

Nyamoma, F.A. (2011).Perception of Peer Counseling on Students' Academic Performance in Schools within Kakamega South District. Unpublished M.Ed Thesis. Masinde Muliro University of Science \& Technology.

Ondeche, R.L. (2005). The Role of Peer Counseling in Behavioral Change and Academic Achievements in Emuhaya District.Unpublished M.Ed Thesis. Maseno University.

Republic of Kenya. (2007). Report of Task Force on Student Discipline and Unrest in Secondary Schools. Nairobi. Jomo Kenyatta Foundation.

UNESCO, (2006).EFA Global Monitoring Report 2006.Literacy for Life. Paris.

Weiten, W. (1983). A Psychology Applied to Modern Life; Adjustments in 80's; Brookes Cole Publishing Company.

\section{Copyright Disclaimer}

Copyright reserved by the author(s)

This article is an open-access article distributed under the terms and conditions of the Creative Commons Attribution license (http://creativecommons.org/licenses/by/3.0/) 